\title{
Long-term effects of clear-cutting and selective cutting on soil methane fluxes in a temperate spruce forest in southern Germany
}

\author{
Xing $\mathrm{Wu}^{\mathrm{a}}{ }^{\mathrm{b}}$, Nicolas Brüggemann ${ }^{\mathrm{c}}$, Rainer Gasche ${ }^{\mathrm{a}}$, Hans Papen ${ }^{\mathrm{a}}$, \\ Georg Willibald ${ }^{a}$, Klaus Butterbach-Bahl ${ }^{\mathrm{a}, *}$ \\ ${ }^{a}$ Karlsruhe Institute of Technology, Institute for Meteorology and Climate Research, Atmospheric Environmental Research (IMK-IFU), \\ Kreuzeckbahnstrasse 19, Garmisch-Partenkirchen, Germany \\ ${ }^{\mathrm{b}}$ State Key Laboratory of Urban and Regional Ecology, Research Center for Eco-environmental Sciences, Chinese Academy of Sciences, P.O. Box 2871, 100085 Beijing, China \\ ${ }^{\mathrm{c}}$ Forschungszentrum Jülich GmbH, Agrosphere Institute (IBG-3), Leo-Brandt-Strasse, 52425 Jülich, Germany
}

\section{A R T I C L E I N F O}

\section{Article history:}

Received 14 February 2011

Received in revised form

10 June 2011

Accepted 19 June 2011

\section{Keywords:}

Methane

Clear-cutting

Selective cutting

Soil temperature

WFPS

Inter-annual variability

\begin{abstract}
A B S T R A C T
Based on multi-year measurements of $\mathrm{CH}_{4}$ exchange in sub-daily resolution we show that clear-cutting of a forest in Southern Germany increased soil temperature and moisture and decreased $\mathrm{CH}_{4} \mathrm{uptake} \mathrm{CH}_{4}$ uptake in the first year after clear-cutting $\left(-4.5 \pm 0.2 \mu \mathrm{g} \mathrm{C} \mathrm{m}^{-2} \mathrm{~h}^{-1}\right)$ was three times lower than during the pre-harvest period $\left(-14.2 \pm 1.3 \mu \mathrm{g} \mathrm{C} \mathrm{m}{ }^{-2} \mathrm{~h}^{-1}\right)$. In contrast, selective cutting did not significantly reduce $\mathrm{CH}_{4}$ uptake. Annual mean uptake rates were $-1.18 \mathrm{~kg} \mathrm{C} \mathrm{ha}^{-1} \mathrm{yr}^{-1}$ (spruce control), $-1.16 \mathrm{~kg} \mathrm{C} \mathrm{ha}^{-1} \mathrm{yr}^{-1}$ (selective cut site) and $-0.44 \mathrm{~kg} \mathrm{C} \mathrm{ha}^{-1} \mathrm{yr}^{-1}$ (clear-cut site), respectively. Substantial seasonal and interannual variations in $\mathrm{CH}_{4}$ fluxes were observed as a result of significant variability of weather conditions, demonstrating the need for long-term measurements. Our findings imply that a stepwise selective cutting instead of clear-cutting may contribute to mitigating global warming by maintaining a high $\mathrm{CH}_{4}$ uptake capacity of the soil.
\end{abstract}

(C) 2011 Elsevier Ltd. All rights reserved.

\section{Introduction}

Methane $\left(\mathrm{CH}_{4}\right)$ is known to be the third most important greenhouse gas after water vapor and $\mathrm{CO}_{2}$ and currently contributes approximately $20 \%$ to global warming (IPCC, 2007). Its concentration in the atmosphere has more than doubled to ca. 1.8 ppmv during the past 200 years, mostly as a result of fossil fuel exploration, expansion of paddy rice cultivation, large-scale animal husbandry of ruminants, biomass burning and landfills (Crutzen, 1991; Le Mer and Roger, 2001). Aerated terrestrial soils act as a global sink for atmospheric $\mathrm{CH}_{4}\left(10-44 \mathrm{Tg} \mathrm{yr}^{-1}\right)$, accounting for up to $10 \%$ of the global atmospheric $\mathrm{CH}_{4} \operatorname{sink}$ (Dutaur and Verchot, 2007). Therefore, slight alterations of the soil $\mathrm{CH}_{4} \operatorname{sink}$ as a result of land management or environmental changes may significantly alter the global methane budget.

Temperate forest upland soils are generally net sinks of $\mathrm{CH}_{4}$ (Butterbach-Bahl and Papen, 2002; Borken et al., 2003). Consumption of atmospheric $\mathrm{CH}_{4}$ by soils is microbially mediated and consequently sensitive to various environmental factors and

\footnotetext{
* Corresponding author.

E-mail address: klaus.butterbach-bahl@kit.edu (K. Butterbach-Bahl).
}

disturbance by management (Ojima et al., 1993; Tate et al., 2007). In view of the huge spatial and temporal variability of environmental factors and the limited number and restricted temporal coverage of long-term field measurements, the annual $\mathrm{CH}_{4}$ sink of temperate forest soils is still afflicted with a high degree of uncertainty, ranging from 0.01 to $0.64 \mathrm{~g} \mathrm{CH}_{4} \mathrm{~m}^{-2} \mathrm{yr}^{-1}$ (Smith et al., 2000; Dutaur and Verchot, 2007).

Forest selective cutting and clear-cutting are the management practices most frequently used for silvicultural rotation and timber harvesting worldwide (Zerva and Mencuccini, 2005; Dannenmann et al., 2007). There is a growing number of studies pointing out that forest clear-cutting might cause a reduction in soil $\mathrm{CH}_{4}$ consumption (Kagotani et al., 2001; Huttunen et al., 2003; Saari et al., 2004), or even switch of soils from being net $\mathrm{CH}_{4}$ sinks to being net sources (Castro et al., 2000; Zerva and Mencuccini, 2005) by altering the biotic and abiotic factors (e.g. soil temperature, soil water content, root activity, soil nitrogen dynamics). However, very little is known about the effects of forest selective cutting on soilatmospheric exchange of $\mathrm{CH}_{4}$ and the existing results are not consistent. Sullivan et al. (2008) reported that methane uptake was not affected by selective cutting in ponderosa pine forest soils within one year of management. A study by Dannenmann et al. (2007) showed that forest selective logging led to a distinct 
reduction in $\mathrm{CH}_{4}$ uptake in the first year after tree felling, but no significant effects of selective cutting on the magnitude of $\mathrm{CH}_{4}$ exchange could be observed at another site $4-6$ years after felling. However, an increased net $\mathrm{CH}_{4}$ consumption after selective logging has also been reported by Bradford et al. (2000), who carried out a laboratory incubation study by collecting intact soil cores from Grizedale Forest, UK. Furthermore, most studies on the effect of forest management on soil $\mathrm{CH}_{4}$ fluxes were performed over a relatively short period ( $\leq 2$ years) or with low measurement frequencies (monthly or weekly), but the long-term effects on soil $\mathrm{CH}_{4}$ consumption still remain unclear.

Therefore, the main objectives of this study were (1) to establish a long-term dataset ( 10 yrs) of continuous sub-daily soil $\mathrm{CH}_{4}$ fluxes from a temperate forest, (2) to evaluate the long-term effects of clear-cutting and selective cutting on $\mathrm{CH}_{4}$ exchange, (3) to assess the impact of environmental factors and soil parameters on $\mathrm{CH}_{4}$ exchange at three sites with different management activities, and (4) to quantify annual $\mathrm{CH}_{4}$ budgets.

\section{Materials and methods}

\subsection{Site and soil descriptions}

The study site, the "Höglwald", was an approximately 100-year-old Norway spruce (Picea abies) forest located in the hilly landscape of Southern Bavaria, Germany $\left(11^{\circ} 4^{\prime} 30^{\prime \prime} \mathrm{E}, 48^{\circ} 17^{\prime} 30^{\prime \prime} \mathrm{N}\right)$ at an elevation of $540 \mathrm{~m}$ above sea level. The climate is sub-oceanic with a mean annual precipitation of $850 \mathrm{~mm}$ and a mean annual temperature of $7.6^{\circ} \mathrm{C}$ (Rothe et al., 2002). The soil is a typic Hapludalf (FAO: dystric cambisol), strongly acidified in the top soil and $\mathrm{N}$-saturated due to long-term heavy atmospheric $\mathrm{N}$ input of more than $35 \mathrm{~kg} \mathrm{~N} \mathrm{ha}^{-1} \mathrm{yr}^{-1}$ (Kreutzer and Weiss, 1998; Huber et al., 2004). The soil $\mathrm{pH}$ value (measured in $\left.\mathrm{CaCl}_{2}\right)$ is 2.9-3.2 in the organic layer and 3.6-4.0 in the uppermost mineral soil layer (Kreutzer, 1995). In July 1999, soil $\mathrm{CH}_{4}$ flux measurements were initiated at three sites with uniform stand and site conditions. Two of these sites (approx. 1.0 ha each) were either completely logged or partially logged at the end of February 2000 . At the selective cutting site, $20 \%$ of the basal tree area was removed, creating gaps of about $20 \mathrm{~m}$ diameter but retaining the stability of the stand (Huber et al., 2004). The impact of soil compaction was avoided by choosing plots that were not affected by forest trails. Approximately two months after forest management, in April 2000, 3-year-old beech trees (Fagus sylvatica L.) were planted at the selective cutting site (SC) in the gaps underneath the remaining spruce stand and throughout the clear-cutting site (CC), while the third site was untreated control (UC). The SC site was situated in the middle between the other two sites, $250 \mathrm{~m}$ NE of UC, and $150 \mathrm{~m} \mathrm{SE}$ of CC. The main soil characteristics at these sites are summarized in Table 1.

\subsection{In-situ measurements of $\mathrm{CH}_{4}$ fluxes}

Complete annual cycles of $\mathrm{CH}_{4}$ fluxes with high resolution were recorded since July 1999 at control and selective cutting sites, and since the beginning of September 1999 at clear-cutting site by fully automated measuring systems. Due to system failure, $\mathrm{CH}_{4}$ flux measurements could not be performed at $\mathrm{SC}$ site from middle of

Table 1

Main characteristics of the three study sites.

\begin{tabular}{|c|c|c|c|}
\hline & $\begin{array}{l}\text { Untreated } \\
\text { control (UC) }\end{array}$ & $\begin{array}{l}\text { Selective } \\
\text { cut (SC) }\end{array}$ & $\begin{array}{l}\text { Clear-cut } \\
(\mathrm{CC})\end{array}$ \\
\hline Throughfall $(\mathrm{mm})^{\mathrm{a}}$ & $703 \pm 89$ & $774 \pm 82$ & $1151 \pm 86$ \\
\hline Bulk density $\left(\mathrm{g} \mathrm{cm}^{-3}\right)^{\mathrm{b}}$ & 0.82 & 0.72 & 0.64 \\
\hline $\begin{array}{l}\text { Organic layer dry } \\
\text { mass }\left(\mathrm{kg} \mathrm{m}^{-2}\right)^{\mathrm{b}}\end{array}$ & $23.1 \pm 4.6$ & $19.0 \pm 2.8$ & $14.4 \pm 2.8$ \\
\hline $\begin{array}{l}\text { Organic layer } \\
\quad \text { thickness }(\mathrm{cm})^{\mathrm{b}}\end{array}$ & 15 & 12 & 9 \\
\hline \multicolumn{4}{|l|}{$\mathrm{NH}_{4}^{+}-\mathrm{N}\left(\mathrm{mg} \mathrm{kg}^{-1} \mathrm{SDW}\right)^{\mathrm{c}}$} \\
\hline Organic layer & $52.8 \pm 8.0$ & $61.4 \pm 16.0$ & $37.4 \pm 7.5$ \\
\hline Mineral soil & $5.5 \pm 1.4$ & $4.6 \pm 0.7$ & $5.1 \pm 0.8$ \\
\hline \multicolumn{4}{|l|}{$\mathrm{NO}_{3}^{-}-\mathrm{N}\left(\mathrm{mg} \mathrm{kg}^{-1} \mathrm{SDW}\right)^{\mathrm{c}}$} \\
\hline Organic layer & $60.6 \pm 3.2$ & $42.8 \pm 7.6$ & $32.7 \pm 7.8$ \\
\hline Mineral soil & $10.5 \pm 2.6$ & $6.9 \pm 1.5$ & $8.6 \pm 2.8$ \\
\hline
\end{tabular}

a Huber et al. (2004), means ( \pm SD) of 2000-2002.

b Rosenkranz et al. (2010). Bulk density values are for $0-4 \mathrm{~cm}$ mineral soils.

c Rosenkranz et al. (2010), means ( \pm SE) of 2003-2004.
June 2003 to November 2004. Detailed descriptions of the automated measuring systems, including design of chambers, gas chromatographic conditions and calculation of $\mathrm{CH}_{4}$ fluxes, can be found in Butterbach-Bahl et al. (1998) and Butterbach-Bahl and Papen (2002). In short, at each site, five chambers of the closed, static type were installed (dimensions: $0.5 \mathrm{~m} \times 0.5 \mathrm{~m} \times 0.15 \mathrm{~m}$, length $\times$ width $\times$ height). The temporal resolution of $\mathrm{CH}_{4}$ flux measurements was $2 \mathrm{~h}$, i.e. $1 \mathrm{~h}$ closure time followed by $1 \mathrm{~h}$ with the chamber lids open, which made it possible to measure $12 \mathrm{CH}_{4}$ flux rates per day with each chamber at each site. $\mathrm{CH}_{4}$ was determined using a gas chromatograph equipped with a flame ionization detector. Air samples from each closed chamber were taken automatically every $15 \mathrm{~min}$ for $3 \mathrm{~min}$ by a membrane pump at a rate of $200 \mathrm{ml} \mathrm{min}^{-1}$. Depending on the value of the regression coefficient $(r), \mathrm{CH}_{4}$ fluxes were either calculated by a linear or an exponential regression model based on the concentrations within chambers during closure. Average gas flux and standard error were calculated from five replicates for all observations.

Chamber positions in the pre-treatment phase (June 1999-February 2000) and following forest management (>February 2000) remained unchanged. This allowed to assess differences in the magnitude of $\mathrm{CH}_{4}$ fluxes between treatment sites for the pre-treatment phase and to document treatment effects following the realization of the different forest management practices. Chambers were randomly distributed across the different treatment sites. It should be noted that such a design is not a full replication of treatments, which also would have been impossible with regard to the size of the forest and logistic constraints for automated gas flux measurements. For the selected cutting site the position of the individual chambers formed a transect including two gaps with one chamber each in the center and the edge of both gaps. The fifth chamber was in the middle of an undisturbed part of SC.

\subsection{Measurements of environmental factors}

Soil temperatures in the organic layer were monitored every minute by PT100 probes (IMKO GmbH, Ettlingen, Germany) in close vicinity to the chambers. Hourly soil moisture measurements were carried out by horizontally installed TDR probes (IMKO GmbH) at $10 \mathrm{~cm}$ soil depth from September 1999 to 2004 at UC, and from February 2000 to 2004 at SC and CC. In situ soil moisture values during 2005-2008 were not available at our sites due to instrumental failure or removal of the sensors. These gaps were filled by a machine-learning technique (support vector machine, SVM). The SVM method is based on a statistical learning algorithm and has been successfully applied to bioinformatics, flood forecasting and soil water prediction (Furey et al., 2000; Chen and Yu, 2007; Wu et al., 2010a). The required input data, creation of the training dataset and prediction of soil water content were described in detail by Wu et al. (2010a). Soil moisture values were converted to percent water-filled pore space (\% WFPS) according to Wu et al. (2010a). Climatic data were obtained from the German Weather Service station Augsburg-Mühlhausen, which was about $20 \mathrm{~km}$ northwest from our study site.

\subsection{Statistical analyses}

The software packages SPSS 13.0 and SigmaPlot 2000 (SPSS Inc., Chicago, USA) were used for statistical analyses. Analyses of variance (ANOVAs) were performed using daily means to test the difference of soil temperature, soil moisture and $\mathrm{CH}_{4}$ flux rates among different years and forest treatments. Linear and nonlinear regression models were used to examine relationships between $\mathrm{CH}_{4}$ fluxes and the measured environmental parameters. Multivariate nonlinear regression analysis was done with SigmaPlot 2000 (SPSS Inc., Chicago, USA).

\section{Results}

\subsection{Environmental and soil conditions}

The annual means of air temperature, precipitation, soil temperature (organic layer) and WFPS at $10 \mathrm{~cm}$ depth from 2000 to 2008 at the three study sites are given in Fig. 1 and Table 2. Compared to the long-term annual mean air temperature $\left(7.6{ }^{\circ} \mathrm{C}\right)$, the period of $2000-2008$ was much warmer $\left(8.8 \pm 0.4{ }^{\circ} \mathrm{C}\right.$, mean \pm SD), especially the years 2000 and 2007. The nine-year mean annual precipitation was $796.7 \mathrm{~mm}$. However, precipitation in the relatively dry years (2003 and 2004) was much lower than in the relatively wet years (2000 and 2002). More than $60 \%$ of the annual precipitation occurred from April to September (Figs. 1 and 2).

The diurnal soil temperature amplitude was greatest at the clearcut site, and still elevated at the selective logged site as compared to the control site (Fig. 1c). During most of the study period, selective 


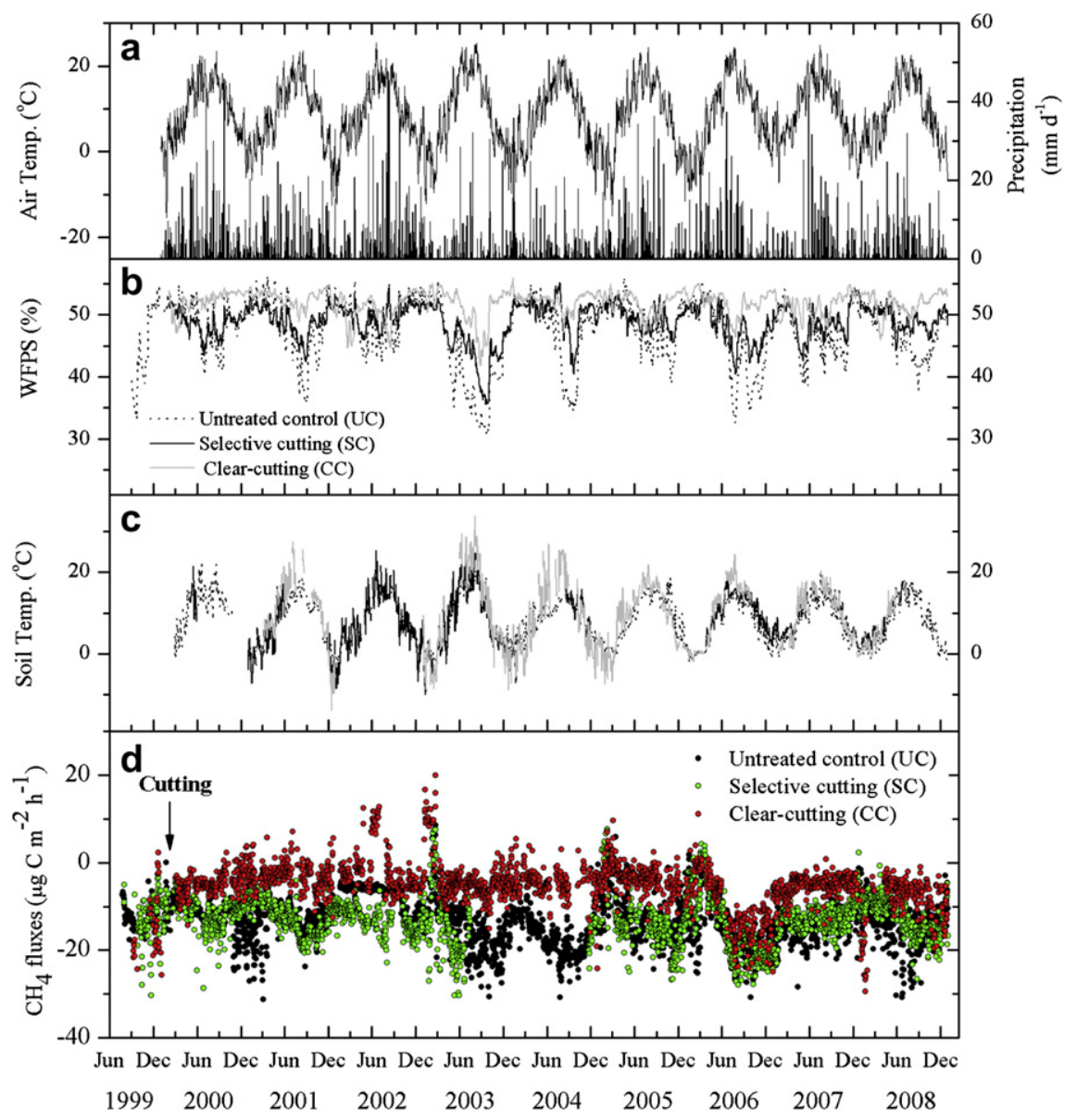

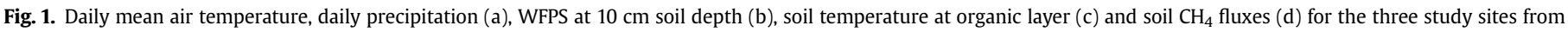
1999 to 2008. Each soil $\mathrm{CH}_{4}$ flux data point represents the daily mean calculated from 60 individual fluxes (i.e. five replicate chambers at 12 time points each per day).

cutting and clear-cutting caused a significant increase in soil temperature of the organic layer in comparison with the control site $(P<0.05$, Table 2$)$, despite an absolute difference of only about $0.5-1.0{ }^{\circ} \mathrm{C}$. Forest selective cutting and clear-cutting substantially increased soil moisture at $10 \mathrm{~cm}$ depth as compared to the control site. The relatively high $(1054 \mathrm{~mm})$ and low $(527 \mathrm{~mm})$ annual precipitation in 2002 and 2003 generated comparatively wet and dry conditions, respectively, which altered soil moisture at all three sites significantly (Table 2). Soil moisture averaged 51.9\% WFPS at CC and $49.0 \%$ WFPS at SC, which were significantly higher $(P<0.05)$ than at the UC site ( $47.4 \%$ WFPS).

\subsection{Seasonal and inter-annual variations in soil $\mathrm{CH}_{4}$ fluxes}

The soils were generally sinks for $\mathrm{CH}_{4}$, with some sporadic $\mathrm{CH}_{4}$ emission events, especially during phases with high soil moisture content and soil freeze/thaw periods. Annual cycles of $\mathrm{CH}_{4}$ fluxes at UC and SC sites showed distinct seasonal patterns (Fig. 1d), which were significantly positively correlated with monthly mean air and soil temperatures $(P<0.01)$. The lowest $\mathrm{CH}_{4}$ uptake was generally observed in February or March and then increased gradually until November (Fig. 2), which implies that the changes of $\mathrm{CH}_{4}$ flux may not only relate to temperature but also to differences between seasons.

Table 2

Annual means $( \pm \mathrm{SD})$ of air temperature, soil temperature (organic layer), WFPS (10 $\mathrm{cm}$ depth) and precipitation at the three study sites.

\begin{tabular}{|c|c|c|c|c|c|c|c|c|}
\hline \multirow[t]{2}{*}{ Year } & \multirow{2}{*}{$\begin{array}{l}\text { Air Temperature } \\
\left({ }^{\circ} \mathrm{C}\right)\end{array}$} & \multirow{2}{*}{$\begin{array}{l}\text { Precipitation } \\
(\mathrm{mm})\end{array}$} & \multicolumn{3}{|c|}{ Soil Temperature $\left({ }^{\circ} \mathrm{C}\right)$} & \multicolumn{3}{|l|}{ WFPS (\%) } \\
\hline & & & UC & SC & $\mathrm{CC}$ & UC & SC & $\mathrm{CC}$ \\
\hline 2000 & $9.3 \pm 6.9$ & 945.7 & $9.1 \pm 4.7^{\mathrm{a}}$ & $9.4 \pm 3.2^{\mathrm{a}}$ & n.d. & $48.8 \pm 3.3^{\mathrm{a}}$ & $48.8 \pm 1.9^{\mathrm{a}}$ & $52.3 \pm 1.6^{\mathrm{b}}$ \\
\hline 2001 & $8.6 \pm 7.4$ & 871.8 & $7.8 \pm 5.5^{\mathrm{a}}$ & $8.7 \pm 6.0^{\mathrm{b}}$ & $9.2 \pm 8.3^{c}$ & $48.3 \pm 4.9^{a}$ & $49.2 \pm 2.3^{b}$ & $52.8 \pm 1.2^{\mathrm{c}}$ \\
\hline 2002 & $9.1 \pm 7.0$ & 1054 & $8.5 \pm 5.3^{\mathrm{a}}$ & $7.6 \pm 6.7^{\mathrm{b}}$ & n.d. & $49.6 \pm 3.2^{\mathrm{a}}$ & $50.0 \pm 1.8^{\mathrm{b}}$ & $51.0 \pm 2.5^{c}$ \\
\hline 2003 & $8.8 \pm 9.0$ & 527.1 & $8.4 \pm 6.3^{\mathrm{a}}$ & $8.3 \pm 8.6^{\mathrm{a}}$ & $9.4 \pm 10.9^{b}$ & $42.7 \pm 7.3^{\mathrm{a}}$ & $45.8 \pm 4.4^{\mathrm{b}}$ & $51.3 \pm 3.1^{c}$ \\
\hline 2004 & $8.4 \pm 7.6$ & 628.5 & $8.4 \pm 3.7^{\mathrm{a}}$ & $7.7 \pm 6.1^{\mathrm{b}}$ & $8.6 \pm 8.5^{c}$ & $47.5 \pm 5.6^{\mathrm{a}}$ & $50.3 \pm 2.7^{b}$ & $52.4 \pm 1.2^{\mathrm{c}}$ \\
\hline 2005 & $8.0 \pm 8.3$ & 889.5 & $8.5 \pm 5.4^{\mathrm{a}}$ & n.d. & $8.7 \pm 6.9^{b}$ & $49.0 \pm 3.7^{\mathrm{a}}$ & $49.8 \pm 1.9^{b}$ & $52.1 \pm 1.6^{\mathrm{c}}$ \\
\hline 2006 & $8.7 \pm 8.3$ & 756.6 & $7.1 \pm 5.4^{\mathrm{a}}$ & $8.5 \pm 5.8^{b}$ & $10.3 \pm 7.6^{c}$ & $45.8 \pm 6.2^{\mathrm{a}}$ & $48.1 \pm 3.2^{\mathrm{b}}$ & $52.0 \pm 1.8^{\mathrm{c}}$ \\
\hline 2007 & $9.4 \pm 6.9$ & 821.4 & $8.1 \pm 5.1^{\mathrm{a}}$ & $9.6 \pm 4.7^{\mathrm{b}}$ & $9.7 \pm 5.8^{\mathrm{b}}$ & $47.9 \pm 4.0^{\mathrm{a}}$ & $49.1 \pm 2.7^{b}$ & $51.6 \pm 1.5^{c}$ \\
\hline 2008 & $9.1 \pm 7.1$ & 675.6 & $7.6 \pm 5.7^{\mathrm{a}}$ & $9.1 \pm 5.1^{\mathrm{b}}$ & $8.2 \pm 5.9^{c}$ & $47.5 \pm 3.7^{\mathrm{a}}$ & $49.4 \pm 1.6^{\mathrm{b}}$ & $51.9 \pm 1.8^{\mathrm{c}}$ \\
\hline Average & $8.8 \pm 7.6$ & 796.7 & $8.2 \pm 5.4^{\mathrm{a}}$ & $8.6 \pm 6.6^{b}$ & $9.1 \pm 8.0^{c}$ & $47.4 \pm 5.2^{\mathrm{a}}$ & $49.0 \pm 2.9^{b}$ & $51.9 \pm 2.0^{c}$ \\
\hline
\end{tabular}

Lowercase letters in the same row for each variable indicate significant differences $(P<0.05)$ among different treatments; n.d., not determined. 


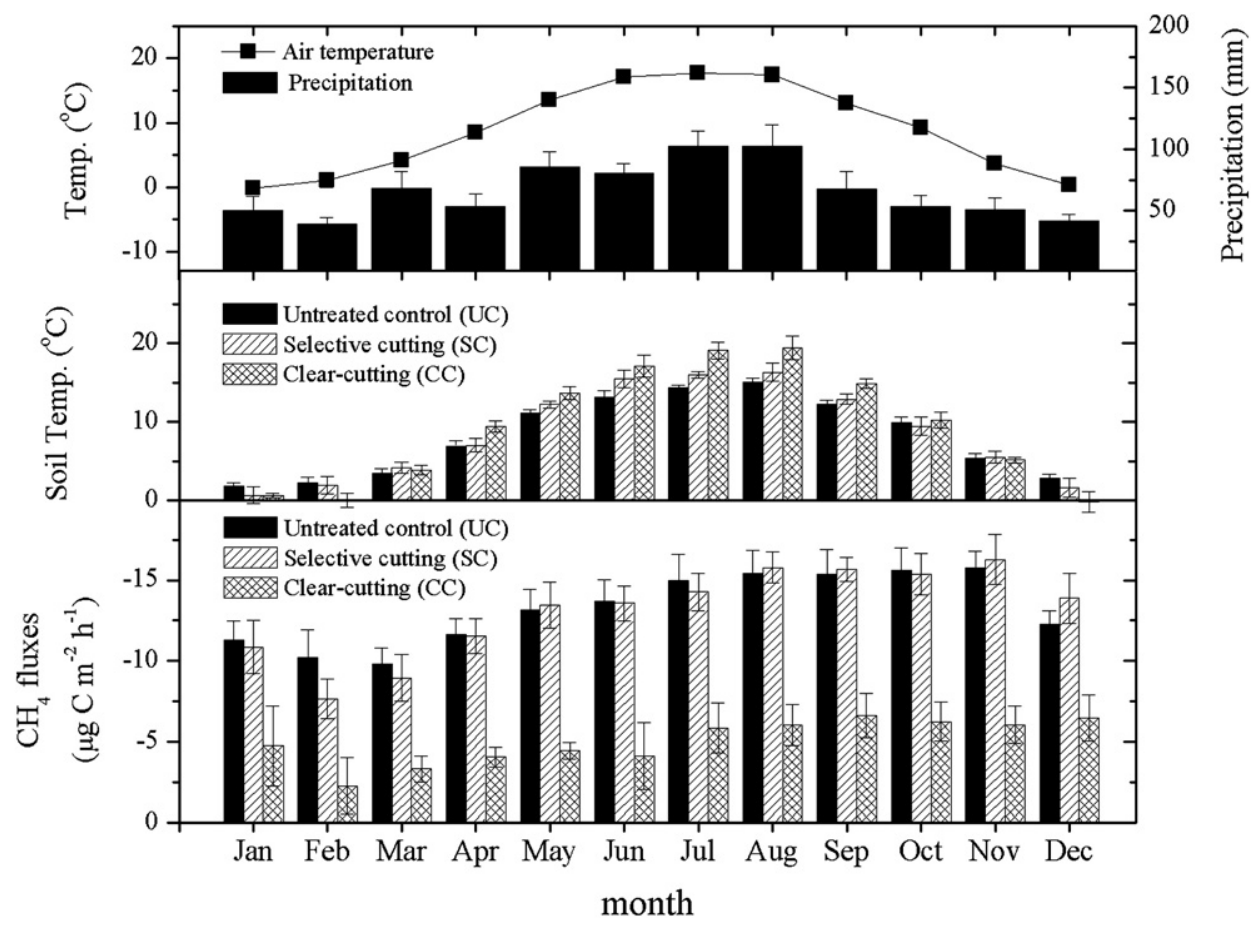

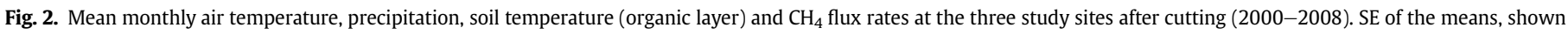
by the error bars, is for sampling times (replicate measurements have first been averaged).

During the study period, the magnitude of soil $\mathrm{CH}_{4}$ fluxes at the three sites varied significantly year by year (Table 3 ). Because the measurements started on July 23,1999, the annual mean values of this year cannot be given. The mean annual $\mathrm{CH}_{4}$ flux in 2002 at UC was $-7.8 \pm 0.2 \mu \mathrm{g} \mathrm{C} \mathrm{m}^{-2} \mathrm{~h}^{-1}\left(-0.68 \mathrm{~kg} \mathrm{C} \mathrm{ha}^{-1} \mathrm{yr}^{-1}\right)$, i.e., lower by a factor of more than two $(P<0.01)$ as compared to 2004 $\left(-1.45 \mathrm{~kg} \mathrm{C} \mathrm{ha}^{-1} \mathrm{yr}^{-1}\right)$ and $2006\left(-1.37 \mathrm{~kg} \mathrm{C} \mathrm{ha}^{-1} \mathrm{yr}^{-1}\right)$, respectively. For the $\mathrm{CC}$ site, mean annual $\mathrm{CH}_{4}$ flux in 2002 was only $-2.3 \pm 0.3 \mu \mathrm{g} \mathrm{C} \mathrm{m}{ }^{-2} \mathrm{~h}^{-1}\left(-0.20 \mathrm{~kg} \mathrm{C} \mathrm{ha}^{-1} \mathrm{yr}^{-1}\right)$, and therefore approx. four times lower $(P<0.001)$ as compared to 2006 and 2008 $\left(-10.3 \pm 0.4 \mu \mathrm{g} \mathrm{C} \mathrm{m}^{-2} \mathrm{~h}^{-1}\right.$ and $-8.4 \pm 0.4 \mu \mathrm{g} \mathrm{C} \mathrm{m}^{-2} \mathrm{~h}^{-1}$, respectively). The mean $\mathrm{CH}_{4}$ fluxes at UC, SC and $\mathrm{CC}$ for the entire observation period after forest management (2000-2008) were $-13.4 \pm 0.1,-13.2 \pm 0.1$ and $-5.0 \pm 0.1 \mu \mathrm{g} \mathrm{C} \mathrm{m}^{-2} \mathrm{~h}^{-1}$, respectively.

The annual coefficients of variation (CV), calculated as the ratio of the standard deviation to the mean value of $\mathrm{CH}_{4}$ fluxes, at UC and SC were in general less than 50\%, except for SC in 2003 and 2006 (Table 3). Owing to relatively large amplitudes of fluxes, the annual

Table 3

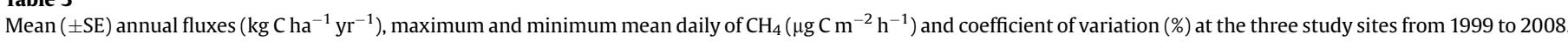

\begin{tabular}{|c|c|c|c|c|c|c|c|c|c|c|c|}
\hline & $1999^{a}$ & $2000^{b}$ & 2001 & 2002 & 2003 & 2004 & 2005 & 2006 & 2007 & 2008 & $\begin{array}{l}\text { Mean } \\
2000-2008\end{array}$ \\
\hline \multicolumn{12}{|c|}{ Untreated control (UC) } \\
\hline Annual mean & $-12.2 \pm 0.3$ & $-12.1 \pm 0.2$ & $-13.2 \pm 0.2$ & $-7.8 \pm 0.2$ & $-14.9 \pm 0.4$ & $-16.5 \pm 0.3$ & $-12.6 \pm 0.3$ & $-15.6 \pm 0.3$ & $-14.1 \pm 0.2$ & $-14.1 \pm 0.3$ & $-13.4 \pm 0.1$ \\
\hline Maximum & -0.1 & -5.2 & -5.6 & -4.1 & 8.5 & -0.5 & 5.9 & 2.0 & -1.3 & -1.6 & 8.5 \\
\hline Minimum & -17.7 & -24.6 & -31.2 & -16.6 & -30.7 & -30.8 & -24.3 & -30.8 & -28.4 & -30.7 & -31.2 \\
\hline$N$ & 115 & 264 & 315 & 316 & 315 & 289 & 344 & 254 & 253 & 325 & 2675 \\
\hline CV (\%) & 24.5 & 28.5 & 28.0 & 41.9 & 42.8 & 27.5 & 42.2 & 34.1 & 27.4 & 33.4 & 39.1 \\
\hline 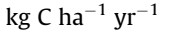 & - & -1.06 & -1.16 & -0.68 & -1.31 & -1.45 & -1.11 & -1.37 & -1.24 & -1.24 & -1.18 \\
\hline \multicolumn{12}{|c|}{ Selective cut (SC) } \\
\hline Annual mean & $-11.9 \pm 0.4$ & $-11.5 \pm 0.2$ & $-12.5 \pm 0.2$ & $-13.1 \pm 0.2$ & $-14.4 \pm 0.6$ & $-16.4 \pm 0.7$ & $-14.6 \pm 0.4$ & $-14.6 \pm 0.4$ & $-12.8 \pm 0.2$ & $-12.4 \pm 0.2$ & $-13.2 \pm 0.1$ \\
\hline Maximum & -3.5 & -0.1 & -4.2 & -6.3 & 7.6 & -12.3 & 7.6 & 4.2 & 2.2 & -0.7 & 7.6 \\
\hline Minimum & -30.3 & -28.7 & -20.6 & -22.9 & -30.3 & -24.2 & -26.8 & -27.9 & -24.4 & -26.6 & -30.3 \\
\hline$N$ & 123 & 224 & 313 & 245 & 162 & 21 & 250 & 349 & 320 & 343 & 2227 \\
\hline CV (\%) & 38.7 & 31.9 & 30.1 & 21.5 & 56.5 & 18.7 & 40.8 & 50.9 & 28.2 & 32.4 & 39.5 \\
\hline $\begin{array}{l}\mathrm{kg} \mathrm{C} \mathrm{ha-1} \mathrm{yr}^{-1} \\
\text { Clear-cut }(\mathrm{CC})\end{array}$ & - & -1.01 & -1.10 & -1.15 & -1.26 & -1.44 & -1.28 & -1.28 & -1.12 & -1.09 & -1.16 \\
\hline Annual mean & $-14.2 \pm 1.3$ & $-4.5 \pm 0.2$ & $-3.0 \pm 0.2$ & $-2.3 \pm 0.3$ & $-3.8 \pm 0.3$ & $-4.6 \pm 0.2$ & $-3.3 \pm 0.2$ & $-10.3 \pm 0.4$ & $-5.3 \pm 0.1$ & $-8.4 \pm 0.4$ & $-5.0 \pm 0.1$ \\
\hline Maximum & 2.3 & 3.7 & 7.1 & 12.8 & 19.9 & 5.4 & 9.6 & 4.0 & 0.8 & -1.0 & 19.9 \\
\hline Minimum & -25.7 & -14.3 & -12.6 & -9.6 & -15.0 & -24.3 & -13.3 & -24.9 & -14.2 & -29.5 & -29.5 \\
\hline$N$ & 35 & 218 & 259 & 232 & 314 & 215 & 262 & 237 & 284 & 214 & 2235 \\
\hline CV (\%) & 52.1 & 57.4 & 94.2 & 211.6 & 135.8 & 74.3 & 87.0 & 63.3 & 42.7 & 61.8 & 97.6 \\
\hline 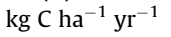 & - & -0.40 & -0.26 & -0.20 & -0.33 & -0.41 & -0.29 & -0.90 & -0.46 & -0.74 & -0.44 \\
\hline
\end{tabular}

$N$, number of valid daily mean $\mathrm{CH}_{4}$ fluxes; $\mathrm{CV}$, coefficient of variation.

a Measurements before clear cutting (from July 23, 1999 to February 29, 2000).

b Data from March to December 2000 were used. 
CV values for CC were usually greater than $50 \%$, especially in the wet year 2002 and the dry year 2003. Throughout the entire observation period 2000-2008, the CC site showed the strongest inter-annual variation of all three experimental sites, with a CV of $97.6 \%$.

\subsection{Effect of forest management on soil $\mathrm{CH}_{4}$ fluxes}

Prior to forest management, the mean soil $\mathrm{CH}_{4}$ fluxes at the three sites were of the same order of magnitude, although $\mathrm{CH}_{4}$ uptake at CC was significantly higher $(P<0.05)$ than at the other two sites (Fig. 3 and Table 3 ). In contrast, there was no significant difference in $\mathrm{CH}_{4}$ fluxes between UC and SC sites before selective cutting.

Following clear-cutting, $\mathrm{CH}_{4}$ uptake rates at the $\mathrm{CC}$ site were significantly reduced $(P<0.0001)$ from $-14.2 \pm 1.3 \mu \mathrm{g} \mathrm{C} \mathrm{m}^{-2} \mathrm{~h}^{-1}$ before cutting to $-4.5 \pm 0.2 \mu \mathrm{g} \mathrm{C} \mathrm{m}{ }^{-2} \mathrm{~h}^{-1}$ in 2000 , the first year after cutting. Moreover, this reduction of $\mathrm{CH}_{4}$ uptake was persistent throughout the entire observation period, i.e., $\mathrm{CH}_{4}$ fluxes remained at this relatively low level during the first several years after cutting and began to increase gradually after more than 5 years after clearcutting, though not reaching the original level (Fig. 3). At CC net $\mathrm{CH}_{4}$ emission events were occasionally observed following heavy rains and during soil freeze/thaw periods. During the almost nine years of continuous measurements after clear-cutting, the average $\mathrm{CH}_{4}$ flux at CC was significantly lower than at the other two sites $(P<0.05)$. In contrast to clear-cutting, selective cutting had no overall significant effect on $\mathrm{CH}_{4}$ fluxes. There was a statistically significant difference between SC and UC sites in some years (Fig. 3), however the sign of the difference was not consistent.

\subsection{Dependence of soil $\mathrm{CH}_{4}$ fluxes on environmental factors}

The relationships between $\mathrm{CH}_{4}$ fluxes and soil temperature were generally weak and could be described best by quadratic functions (Fig. 4). Correlations between soil temperature and $\mathrm{CH}_{4}$ fluxes were higher at SC and CC, with $r^{2}$ values of 0.18 and 0.11 , respectively, than at UC with an $r^{2}$ value of 0.08 . In order to quantify the sensitivity of $\mathrm{CH}_{4}$ fluxes to temperature, $Q_{10}$ values were calculated for a temperature increase from $5{ }^{\circ} \mathrm{C}$ to $15{ }^{\circ} \mathrm{C}$ in the organic layer. The multi-year mean $Q_{10}$ values ( $\pm \mathrm{SE}$ ) were $1.26 \pm 0.13,1.38 \pm 0.15$ and $1.67 \pm 0.32$ for UC, SC and CC, respectively.

Correlations between $\mathrm{CH}_{4}$ fluxes and WFPS in $10 \mathrm{~cm}$ soil depth were generally weak but significant $(P<0.001)$ at all three sites and could be described best by linear regressions (Fig. 5). The correlation analysis revealed similar basic dependency patterns of $\mathrm{CH}_{4}$ fluxes on soil moisture at all sites, i.e. uptake of atmospheric $\mathrm{CH}_{4}$ by the soils decreased linearly with increasing WFPS. The multivariate nonlinear regression analysis showing the conjunct effect of soil temperature and WFPS on $\mathrm{CH}_{4}$ fluxes indicated that the dominant environmental factor affecting the magnitude of $\mathrm{CH}_{4}$ fluxes at UC and SC was soil moisture rather than soil temperature. However, owing to a relatively narrow range of WFPS values at CC, the dependency of soil $\mathrm{CH}_{4}$ fluxes on soil temperature was significant at a higher level as compared to soil moisture. Linear regression analysis showed that the annual mean $\mathrm{CH}_{4}$ fluxes at all sites were positively correlated with annual cumulative precipitation (Fig. 6).

\section{Discussion}

\subsection{Comparison with other studies}

To our knowledge, this paper provides the longest time scale of continuous sub-daily measurements of soil-atmosphere exchange of $\mathrm{CH}_{4}$ in a temperate forest. The results obtained in this study demonstrate distinct seasonal as well as inter-annual variations in $\mathrm{CH}_{4}$ fluxes at control and managed Höglwald sites. The seasonal variations in $\mathrm{CH}_{4}$ fluxes generally followed the intra-annual changes in air and soil temperatures, with lowest uptake rates during winter and early spring, and highest $\mathrm{CH}_{4}$ uptake during late summer and autumn. This is in good agreement with previous observations (e.g. Ambus and Christensen, 1995; Priemé and Christensen, 1997; Butterbach-Bahl and Papen, 2002; Teepe et al., 2004; Guckland et al., 2009). The annual mean $\mathrm{CH}_{4}$ flux $(-0.68$ to $-1.45 \mathrm{~kg}$ $\mathrm{Cha}^{-1} \mathrm{yr}^{-1}$ ) at the spruce control site of this study is consistent with earlier publications for this site (Butterbach-Bahl and Papen, 2002; Butterbach-Bahl et al., 2002) covering the period from 1994 to 1997. Moreover, our results fall within the range of annual mean $\mathrm{CH}_{4}$

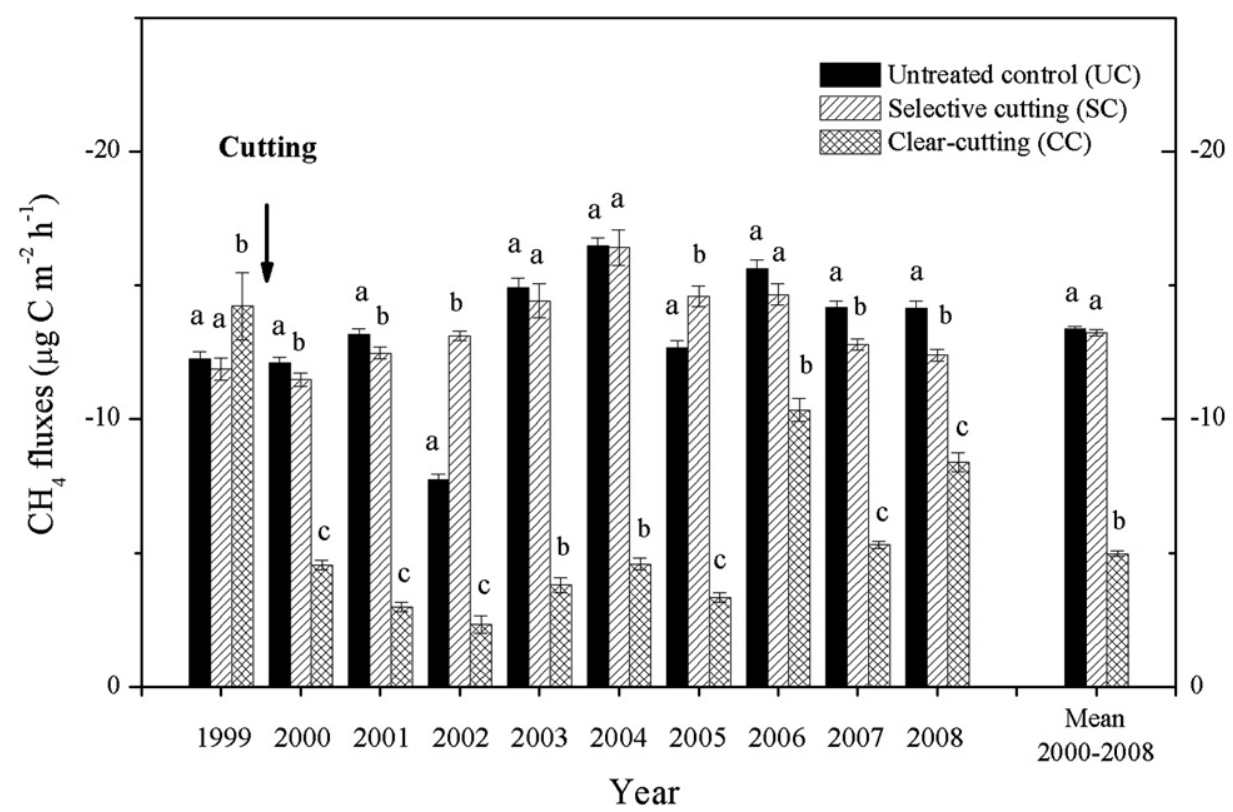

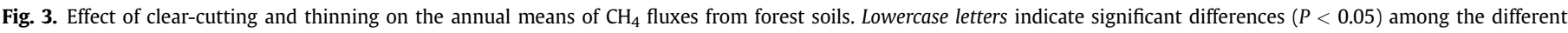
treatments. SE of the means, shown by the error bars, is for sampling times (five replicate chambers have first been averaged). 


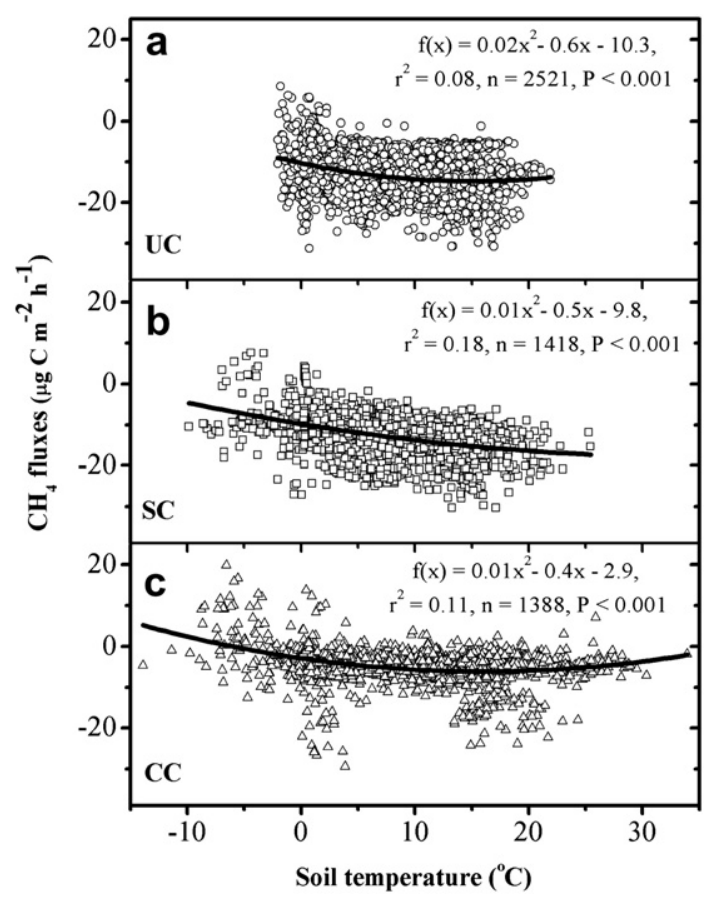

Fig. 4. Relationship between daily mean $\mathrm{CH}_{4}$ fluxes and soil temperature of the organic layer for UC (a), SC (b) and CC (c); n, number of valid $\mathrm{CH}_{4}$ fluxes.

fluxes reported from several field measurements for temperate coniferous forests in Europe (Priemé and Christensen, 1997; Borken et al., 2000, 2003; Borken and Beese, 2006). However, consumption was lower than in some studies of temperate coniferous forests in North America (Yavitt et al., 1990; Castro et al., 1992; Gulledge et al., 2004). The underlying mechanism for this regional difference in $\mathrm{CH}_{4}$ fluxes in temperate forest soils remains unclear, and its elucidation is impeded by the low number of available year-round

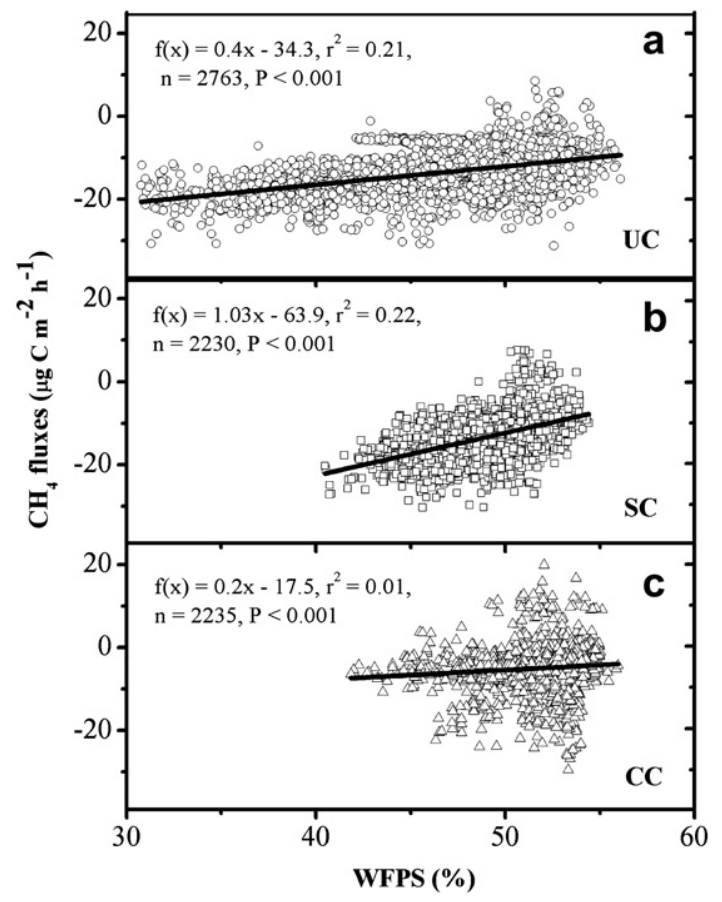

Fig. 5. Relationship between daily mean $\mathrm{CH}_{4}$ fluxes and water-filled pore space at a depth of $10 \mathrm{~cm}$ for UC (a), SC (b) and CC (c); $n$, number of valid $\mathrm{CH}_{4}$ fluxes.

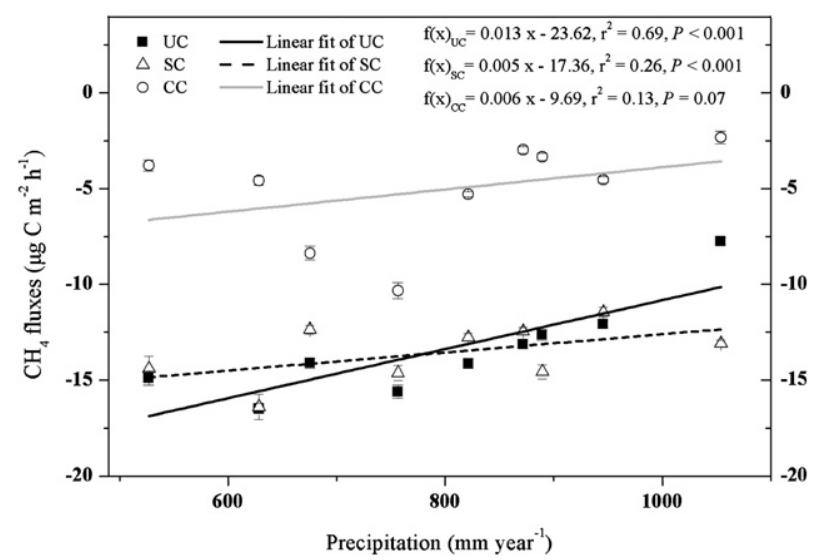

Fig. 6. Relationship between annual mean $\mathrm{CH}_{4}$ fluxes and precipitation for the three study sites. SE of the means, shown by the error bars, is for sampling times (five replicate chambers have first been averaged).

measurements of $\mathrm{CH}_{4}$ fluxes in temperate forests. Poor drainage of clay rich-soils and low gas diffusivity (Brumme and Borken, 1999; Borken et al., 2006), relatively high $\mathrm{N}$ deposition (Bergström and Jansson, 2006) and differences in soil $\mathrm{N}$ availability (Brumme and Borken, 1999; Butterbach-Bahl et al., 1998) are some factors that have been shown to contribute to the lower $\mathrm{CH}_{4}$ uptake capacity of temperate forest soils in Europe. However, in view of large spatial and inter-annual variations in $\mathrm{CH}_{4}$ fluxes, the rates found in this study (approx. $0.8 \mathrm{~kg} \mathrm{C} \mathrm{ha}^{-1} \mathrm{yr}^{-1}$ at UC) are in agreement with previous reports on the mean $\mathrm{CH}_{4}$ sink strength of temperate coniferous forest soils (1.0-2.0 $\mathrm{kg} \mathrm{C} \mathrm{ha}^{-1} \mathrm{yr}^{-1}$, Borken et al., 2000; Butterbach-Bahl and Papen, 2002). This result indicates that more long-term continuous measurements over several years with high temporal resolution are needed to reliably estimate the mean $\mathrm{CH}_{4}$ uptake potential of temperate forest soils.

\subsection{Effect of forest management on environmental factors}

Generally, clear-cutting and selective cutting are thought to alter the thermal properties and the energy balance at the soil surface due to the removal or reduction of the forest canopy. In the present study, clear-cutting and selective cutting not only induced a significant increase in soil temperature, but also caused greater ranges of soil temperature, which was in line with other findings (Castro et al., 2000; Zerva and Mencuccini, 2005). Although some studies have reported an increase in soil bulk density after logging (e.g. Yashiro et al., 2008), the bulk densities as well as the thickness and dry mass of the organic layer at our logged sites were lower as compared to the control site (Table 1 ). This may be ascribed to the fact that these values were determined about three years after logging. A significant increase in soil water content as a result of the reduction of evapotranspiration and hence water uptake by trees has been documented not only in clear-cutting studies (Castro et al., 2000; Zerva and Mencuccini, 2005), but also in a study on forest selective cutting (Dannenmann et al., 2007), which is consistent with our findings.

\subsection{Effect of clear-cutting on soil $\mathrm{CH}_{4}$ fluxes}

The uptake of atmospheric $\mathrm{CH}_{4}$ by soils is mainly controlled by the activity of methanotrophic bacteria, which can be strongly affected by soil disturbances, such as land-use change and agricultural practices (Ojima et al., 1993; Le Mer and Roger, 2001). Many publications have indicated that the inhibition of $\mathrm{CH}_{4}$ oxidation due 
to soil disturbance may persist for years to decades (Mosier et al., 1991; Ojima et al., 1993; Priemé et al., 1997). In the present study, the mean $\mathrm{CH}_{4}$ uptake rate in the first year following clear-cutting $\left(-4.5 \pm 0.2 \mu \mathrm{g} \mathrm{C} \mathrm{m}{ }^{-2} \mathrm{~h}^{-1}\right)$ was approx. three times lower than during the pre-harvest period $\left(-14.2 \pm 1.3 \mu \mathrm{g} \mathrm{C} \mathrm{m}^{-2} \mathrm{~h}^{-1}\right)$ and at the control site in the same year $\left(-12.1 \pm 0.2 \mu \mathrm{g} \mathrm{C} \mathrm{m} \mathrm{m}^{-2} \mathrm{~h}^{-1}\right)$. Several previous investigations have shown that $\mathrm{CH}_{4}$ consumption in forest soils could be significantly reduced by clear-cutting (Bradford et al., 2000; Kähkönen et al., 2002; Huttunen et al., 2003), albeit with different duration of the effect. Saari et al. (2004) reported for a Norway spruce forest in south-eastern Finland that the inhibition of $\mathrm{CH}_{4}$ consumption by clear-cutting lasted only about one year, and the difference between clear-cut and control sites was no longer significant after 15-19 months. In two pine forest soils in Florida, Castro et al. (2000) found that the decrease of $\mathrm{CH}_{4}$ oxidation activity after clear-cutting persisted until the end of the study (approx. two years after clear-cutting). In contrast, the results of our study clearly showed that the reduced $\mathrm{CH}_{4}$ consumption due to clear-cutting could last for a decade or even longer (Fig. 3) and highlight the importance of long-term observations.

The decrease in $\mathrm{CH}_{4}$ consumption is often attributed to the increase in soil mineral $\mathrm{N}$ contents after clear-cutting (Bradford et al., 2000; Yashiro et al., 2008), since both $\mathrm{NH}_{4}^{+}$(Steinkamp et al., 2001 ) and $\mathrm{NO}_{3}^{-}$(Kähkönen et al., 2002) could inhibit $\mathrm{CH}_{4}$ oxidation. However, a study by Castro et al. (2000) showed that a 10-fold increase of soil $\mathrm{NH}_{4}^{+}$concentration due to clear-cutting had no effect on $\mathrm{CH}_{4}$ consumption. Moreover, in the present study both $\mathrm{NH}_{4}^{+}$and $\mathrm{NO}_{3}^{-}$concentrations in organic layer and mineral soil at CC were even lower than that at UC during 2003-2004 but elevated in the year 2000, i.e. the year of clear-cutting (Huber et al., 2004). This indicates that the increase in $\mathrm{NH}_{4}^{+}$and $\mathrm{NO}_{3}^{-}$concentrations may last only for a relatively short period due to the increased soil $\mathrm{C}$ and $\mathrm{N}$ turnover rates after forest disturbance (Saari et al., 2004; Dannenmann et al., 2006). This is followed by a decrease of $C$ and $\mathrm{N}$ pools over time even below the initial values before clear-cutting as a result of increased $\mathrm{C}$ and $\mathrm{N}$ losses to the atmosphere and groundwater. The contrasting findings, however, point out that the impact of management on the mineral $\mathrm{N}$ content of the soil cannot be the key determinant of soil $\mathrm{CH}_{4}$ fluxes in this study. Another possibility is that higher $\mathrm{N}$ turnover rates could inhibit soil $\mathrm{CH}_{4}$ consumption, as pointed out by Mosier et al. (1991). This could be a relevant mechanism for the Höglwald, as an earlier study at these sites demonstrated that the soil $\mathrm{C}$ and $\mathrm{N}$ turnover rates were significantly higher at the clear-cut site as compared to the control (Rosenkranz et al., 2010).

Much more evident than the potential role of $\mathrm{N}$ turnover in regulating soil $\mathrm{CH}_{4}$ fluxes is the fact that the microbially mediated $\mathrm{CH}_{4}$ consumption is substantially limited by the diffusivity of $\mathrm{CH}_{4}$ and $\mathrm{O}_{2}$ availability in the soil (Le Mer and Roger, 2001), which in turn are regulated by the soil water content (Borken et al., 2006; Guckland et al., 2009). In our study, the long time periods of significantly higher soil moisture values after clear-cutting may be the major factor leading to the drastic reduction of $\mathrm{CH}_{4}$ fluxes at the clear-cutting site as compared to control site. Due to the relatively higher throughfall and significantly lower evapotranspiration, the soil water content remained at a higher level at CC throughout the years 2001-2008, i.e. WFPS was never less than 40\% (Fig. 1b). High soil water contents were generally found to inhibit $\mathrm{CH}_{4}$ oxidation, as well as to increase $\mathrm{CH}_{4}$ production in soils (Le Mer and Roger, 2001; Butterbach-Bahl and Papen, 2002; Tate et al., 2007; Wu et al., 2010b). Several studies have demonstrated that the anaerobic condition caused by increased soil water contents after forest management was one of the main reasons for the decreasing soil $\mathrm{CH}_{4}$ uptake or increasing emission (Castro et al., 2000; Dannenmann et al., 2006), which was further supported by our results. Moreover, occasional $\mathrm{CH}_{4}$ emissions were observed after some rainfall events in our study, especially at the CC site. Castro et al. (2000) also reported $\mathrm{CH}_{4}$ emissions after major rainfall events three to eight times higher than before clear-cutting despite similar soil moisture levels, indicating that clear-cutting could not only increase soil moisture, but may promote production of $\mathrm{CH}_{4}$ in deeper soil layers and in the organic layer. This is in agreement with results of earlier studies at our spruce control site (Butterbach-Bahl and Papen, 2002), where specifically for the organic layer and soil layers deeper than $20 \mathrm{~cm}$ soil depth a continuing $\mathrm{CH}_{4}$ production activity could be demonstrated, though the soil in principle acted as a net $\mathrm{CH}_{4} \operatorname{sink}$.

\subsection{Effect of selective cutting on soil $\mathrm{CH}_{4}$ fluxes}

In contrast to clear-cutting, selective cutting did not significantly reduce $\mathrm{CH}_{4}$ fluxes throughout our long-term experiment. Published studies on the effect of forest selective cutting on soil $\mathrm{CH}_{4}$ flux were rather scarce, especially for long-term data, and sometimes contradictory. Dannenmann et al. (2007) reported a distinct decrease in soil $\mathrm{CH}_{4}$ uptake in the first year after thinning of a beech forest, but no significant changes of $\mathrm{CH}_{4}$ fluxes at another nearby site $4-6$ years after selective cutting. One laboratory study done by Bradford et al. (2000) showed a significantly higher $\mathrm{CH}_{4}$ uptake in soil cores from a selectively logged oak forest site than that from an undisturbed site. However, the reason for the stimulation of $\mathrm{CH}_{4}$ uptake at the selectively logged site remained unclear. Based on one year of field measurements, Sullivan et al. (2008) found that selective logging had no significant short-term effect on soil $\mathrm{CH}_{4}$ uptake because the forest floor density was not substantially reduced during logging and, thus, $\mathrm{CH}_{4}$ diffusion into the soil was not affected. In our study, organic layer thickness and dry mass were slightly decreased due to the lower supply of litter by cutting $20 \%$ of the basal trees. However, planting 3-year-old beech seedlings in the gaps two months after selective cutting led to an increase in understory plant biomass. Though the multi-year mean soil water content at SC (49.0\% WFPS) was significantly higher $(P<0.05)$ than at UC $(47.4 \%$ WFPS $)$, this change might not have been enough to affect gas diffusion into the soil. Overall, the results of our long-term continuous measurements suggest that forest selective cutting with suitable cutting intensity seems to contribute to mitigating global warming by maintaining a relatively high $\mathrm{CH}_{4}$ uptake capacity of the soil as compared to clear-cutting.

\subsection{Dependence of soil $\mathrm{CH}_{4}$ fluxes on environmental factors}

Soil temperature is widely reported to be positively correlated with $\mathrm{CH}_{4}$ uptake (e.g. Castro et al., 1995; Dannenmann et al., 2007). In this study, generally low but statistically highly significant $(P<0.001)$ correlations were found between soil temperature and $\mathrm{CH}_{4}$ fluxes, which was in accordance with the findings of other authors (Borken et al., 2000; Zerva and Mencuccini, 2005). Castro et al. (1995) reported that soil temperature was an important controller of $\mathrm{CH}_{4}$ consumption at low temperatures, but had no significant effect of $\mathrm{CH}_{4}$ uptake at temperatures between 10 and $20{ }^{\circ} \mathrm{C}$, indicating that $\mathrm{CH}_{4}$ diffusivity might become the limiting factor of $\mathrm{CH}_{4}$ uptake rates above a certain temperature threshold. This is confirmed by a study by Steinkamp et al. (2001), who also showed a strong temperature sensitivity of $\mathrm{CH}_{4}$ fluxes in forest soils at temperatures $<10^{\circ} \mathrm{C}$, which diminished at higher temperatures. The multi-year mean $Q_{10}$ values found for UC (1.26 \pm 0.13$)$, SC $(1.38 \pm 0.15)$ and CC $(1.67 \pm 0.32)$ are in good agreement with the values (1.0-2.0) reported by others (Borken et al., 2000; Steinkamp et al., 2001; Butterbach-Bahl and Papen, 2002). 
Soil water content is usually considered to be an important regulator of $\mathrm{CH}_{4}$ fluxes in soils (Castro et al., 2000; Borken et al., 2006; Guckland et al., 2009). Weak but significant linear regressions between $\mathrm{CH}_{4}$ fluxes and soil moisture, expressed as WFPS, were observed in the present study, which was in accordance with previous studies (Butterbach-Bahl and Papen, 2002; Borken et al., 2003). In general, soil moisture at both extremely low and high levels have been found to have a strong inhibitory effect on $\mathrm{CH}_{4}$ uptake by soils (Castro et al., 1995; Borken et al., 2006; Wu et al., 2010b), pointing towards an inhibition of methanotrophic activity by drought stress in the former case, and to an inhibition of gas diffusion in the latter. In addition to low gas diffusivity into the soil caused by high soil moisture, the methanogenic activity might also be stimulated, leading to increased methane production offsetting overall soil methane uptake. However, there was no evidence of drought stress in our study, since soil moisture of our study sites never reached such low values. The negative correlation between soil moisture and $\mathrm{CH}_{4}$ flux was less pronounced at $\mathrm{CC}$ than at UC and SC, most likely due to the significantly higher but narrower range of soil water content at CC.

Changes in annual precipitation amount and distribution have been found to affect seasonal and inter-annual variation in $\mathrm{CH}_{4}$ exchange (Priemé and Christensen, 1997; Guckland et al., 2009). Our results showed a distinct decrease in $\mathrm{CH}_{4}$ uptake with increasing annual precipitation (Fig. 6). The obvious reduction of precipitation from $1054 \mathrm{~mm}$ in 2002 to $527.1 \mathrm{~mm}$ in 2003 correlated with an increase in $\mathrm{CH}_{4}$ uptake by $10-95 \%$ at our sites. Similar results were also reported by Borken et al. (2006), who found a significant increase of $\mathrm{CH}_{4}$ uptake during artificial summer droughts by exclusion of throughfall. It is noteworthy that we also observed weak but significant $\mathrm{CH}_{4}$ emission peaks during soil freeze/thaw periods in some winters (especially in 2003 and 2005). Although snow cover and the formation of ice during winter can reduce $\mathrm{CH}_{4}$ uptake activity by acting as a gas diffusion barrier (Borken et al., 2006; Guckland et al., 2009), short-term $\mathrm{CH}_{4}$ emissions have also been reported at low temperatures or during thawing (Butterbach-Bahl and Papen, 2002; Heyer et al., 2002; Wu et al., 2010b). Our results suggest that $\mathrm{CH}_{4}$ fluxes during winter periods should be considered for better estimates of the regional or global $\mathrm{CH}_{4}$ budget, since there is a globally increasing likelihood of extreme climate events (e.g. severe snow events, prolonged freezing periods) with global climate change.

\section{Conclusions}

To the best of our knowledge, this study provides for the first time almost ten years of data of long-term continuous measurements of $\mathrm{CH}_{4}$ soil-atmosphere exchange in a temperate forest, including different forest management practices (clear-cutting and selective cutting). On the basis of these long-term observations, we documented the annual budgets of $\mathrm{CH}_{4}$ fluxes at three differently managed forest sites with a high degree of accuracy. All sites were net sinks for atmospheric $\mathrm{CH}_{4}$, though the sink strength varied markedly on seasonal as well as inter-annual scales. $\mathrm{CH}_{4}$ fluxes at our three sites were weakly but significantly correlated with soil temperature and soil moisture, indicating that other factors may exert a strong effect on $\mathrm{CH}_{4}$ fluxes.

Forest clear-cutting and selective cutting strongly changed the microclimate by increasing soil temperature and soil moisture. Clear-cutting significantly reduced the soil $\mathrm{CH}_{4}$ uptake by about $60 \%$ as compared to the control site, which was most likely due to the more anaerobic conditions resulting from the higher soil water content. Moreover, our results also showed that clear-cutting will reduce the sink strength of forest soils for atmospheric $\mathrm{CH}_{4}$ for several years. In contrast to clear-cutting, forest selective cutting did not significantly reduce $\mathrm{CH}_{4}$ uptake throughout our long-term measurement. Thus, selective cutting and replacing rotation forests by forests with continuous cover, instead of periodic clearcutting, may be a more sustainable way of forest harvesting with regard to climate protection due to the avoidance of negative effects on the $\mathrm{CH}_{4}$ uptake capacity of upland temperate forest soils.

\section{Acknowledgments}

This research was supported by the Helmholtz Association of German Research Centers in the framework of the programoriented funding (POF) period 2004-2008 and by the Integrated Project NitroEurope IP, funded by the European Commission. We thank Benjamin Wolf (IMK-IFU) for his support with vector machine modeling and Prof. Bojie Fu (State Key Laboratory of Urban and Regional Ecology, Beijing, China) for critical reading and valuable discussions. One of the authors, Xing Wu, would like to thank the Helmholtz Association of German Research Centers and the China Scholarship Council (CSC) for providing financial support within the Junior Scientists Exchange Program. We also thank the two anonymous reviewers whose comments greatly improved the clarity and depth of the manuscript.

\section{References}

Ambus, P., Christensen, S., 1995. Spatial and seasonal nitrous oxide and methane fluxes in Danish forest-, grassland- and agroecosystems. Journal of Environmental Quality 24, 993-1001.

Bergström, A.K., Jansson, M., 2006. Atmospheric nitrogen deposition has caused nitrogen enrichment and eutrophication of lakes in the northern hemisphere. Global Change Biology 12, 635-643.

Borken, W., Brumme, R., Xu, Y.J., 2000. Effects of prolonged soil drought on $\mathrm{CH}_{4}$ oxidation in a temperate spruce forest. Journal of Geophysical Research 105, 7079-7088.

Borken, W., Xu, Y.J., Beese, F., 2003. Conversion of hardwood forests to spruce and pine plantations strongly reduced soil methane sink in Germany. Global Change Biology 9, 956-966.

Borken, W., Beese, F., 2006. Methane and nitrous oxide fluxes of soils in pure and mixed stands of European beech and Norway spruce. European Journal of Soil Science 57, 617-625.

Borken, W., Davidson, E.A., Savage, K., Sundquist, E.T., Steudler, P., 2006. Effect of summer throughfall exclusion, summer drought, and winter snow cover on methane fluxes in a temperate forest soil. Soil Biology and Biochemistry 38 1388-1395.

Bradford, M.A., Ineson, P., Wookey, P.A., Lappin-Scott, H.M., 2000. Soil $\mathrm{CH}_{4}$ oxidation: response to forest clear-cutting and thinning. Soil Biology and Biochemistry 32, 1035-1038.

Brumme, R., Borken, W., 1999. Site variation in methane oxidation as affected by atmospheric deposition and type of temperate forest ecosystem. Global Biogeochemical Cycles 13, 493-501.

Butterbach-Bahl, K., Gasche, R., Huber, C., Kreutzer, K., Papen, H., 1998. Impact of Ninput by wet deposition on $\mathrm{N}$-trace gas fluxes and $\mathrm{CH}_{4}$-oxidation in spruce forest ecosystems of the temperate zone in Europe. Atmospheric Environment $32,559-564$

Butterbach-Bahl, K., Papen, H., 2002. Four years continuous record of $\mathrm{CH}_{4}$-exchange between the atmosphere and untreated and limed soil of a $\mathrm{N}$-saturated spruce and beech forest ecosystem in Germany. Plant and Soil 240, 77-90.

Butterbach-Bahl, K., Rothe, A., Papen, H., 2002. Effect of tree distance on $\mathrm{N}_{2} \mathrm{O}$ and $\mathrm{CH}_{4}$-fluxes from soils in temperate forest ecosystems. Plant and Soil 240 91-103.

Castro, M.S., Steudler, P.A., Melillo, J.M., Aber, J.D., Millham, S., 1992. Exchange of $\mathrm{N}_{2} \mathrm{O}$ and $\mathrm{CH}_{4}$ between the atmosphere and soils in spruce-fir forests in the northeastern United States. Biogeochemistry 18, 119-135.

Castro, M.S., Steudler, P.A., Melillo, J.M., 1995. Factors controlling atmospheric methane consumption by temperate forest soils. Global Biogeochemical Cycles $9,1-10$.

Castro, M.S., Gholz, H.L., Clark, K.L., Steudler, P.A., 2000. Effects of forest harvesting on soil methane fluxes in Florida slash pine plantations. Canadian Journal of Forest Research 30, 1534-1542.

Chen, S.T., Yu, P.S., 2007. Pruning of support vector networks on flood forecasting. Journal of Hydrology 347, 67-78.

Crutzen, P.J., 1991. Methane's sinks and sources. Nature 350, 380-381.

Dannenmann, M., Gasche, R., Ledebuhr, A., Papen, H., 2006. Effects of forest management on soil $\mathrm{N}$ cycling in beech forests stocking on calcareous soils. Plant and Soil 287, 279-300.

Dannenmann, M., Gasche, R., Ledebuhr, A., Holst, T., Mayer, H., Papen, H., 2007. The effect of forest management on trace gas exchange at the 
pedosphere-atmosphere interface in beech (Fagus sylvatica L.) forests stocking on calcareous soils. European Journal of Forest Research 126, 331-346.

Dutaur, L., Verchot, L.V., 2007. A global inventory of the soil $\mathrm{CH}_{4}$ sink. Global Biogeochemical Cycles 21 GB 4013.

Furey, T.S., Cristianini, N., Duffy, N., Bednarski, D.W., Schummer, M., Haussler, D. 2000. Support vector machine classification and validation of cancer tissue samples using microarray expression data. Bioinformatics 16, 906-914.

Guckland, A., Flessa, H., Prenzel, J., 2009. Controls of temporal and spatial variability of methane uptake in soils of a temperate deciduous forest with different abundance of European beech (Fagus sylvatica L.). Soil Biology and Biochemistry 41, 1659-1667.

Gulledge, J., Hrywna, Y., Cavanaugh, C., Steudler, P.A., 2004. Effects of long-term nitrogen fertilization on the uptake kinetics of atmospheric methane in temperate forest soils. FEMS Microbiology Ecology 49, 389-400.

Heyer, J., Berger, U., Kuzin, I.L., Yakovlev, O.N., 2002. Methane emissions from different ecosystem structures of the subarctic tundra in Western Siberia during midsummer and during the thawing period. Tellus B 54, 231-249.

Huber, C., Weis, W., Baumgarten, M., Göttlein, A., 2004. Spatial and temporal variation of seepage water chemistry after femel and small scale clear-cutting in a N-saturated Norway spruce stand. Plant and Soil 267, 23-40.

Huttunen, J.T., Nykänen, H., Martikainen, P.J., Nieminen, M., 2003. Fluxes of nitrous oxide and methane from drained peatlands following forest clear-felling in southern Finland. Plant and Soil 255, 457-462.

IPCC, 2007. Climate Change 2007: The Physical Science Basis. Cambridge University Press, Cambridge, UK. Contribution of Working Group I to the Fourth Assessment Report of the Intergovernmental Panel on Climate Change.

Kagotani, Y., Hamabata, E., Nakajima, T., 2001. Seasonal and spatial variations and the effects of clear-cutting in the methane absorption rates of a temperate forest soil. Nutrient Cycling in Agroecosystems 59, 169-175.

Kähkönen, M.A., Wittmann, C., Ilvesniemi, H., Westman, C.J., SalkinojaSalonen, M.S., 2002. Mineralization of detritus and oxidation of methane in acid boreal coniferous forest soils: seasonal and vertical distribution and effects of clear-cut. Soil Biology and Biochemistry 34, 1191-1200.

Kreutzer, K., 1995. Effects of forest liming on soil processes. Plant and Soil 168-169, $447-470$.

Kreutzer, K., Weiss, T., 1998. The Höglwald field experiments-aims, concept and basic data. Plant and Soil 199, 1-10.

Le Mer, J., Roger, P., 2001. Production, oxidation, emission and consumption of methane by soils: a review. European Journal of Soil Biology 37, 25-50.

Mosier, A., Schimel, D., Valentine, D., Bronson, K., Parton, W., 1991. Methane and nitrous oxide fluxes in native, fertilized and cultivated grasslands. Nature 350, $330-332$.

Ojima, D.S., Valentine, D.W., Mosier, A.R., Parton, W.J., Schimel, D.S., 1993. Effect of land-use change on methane oxidation in temperate forest and grassland soils. Chemosphere 26, 675-685.

Priemé, A., Christensen, S., 1997. Seasonal and spatial variation of methane oxidation in a Danish spruce forest. Soil Biology and Biochemistry 29, 1165-1172.
Priemé, A., Smith, K.A., Christensen, S., Dobbie, K.E., 1997. Slow increase in rate of methane oxidation in soils with time following land use change from arable agriculture to woodland. Soil Biology and Biochemistry 29, 1269-1273.

Rosenkranz, P., Dannenmann, M., Brüggemann, N., Papen, H., Berger, U., Zumbusch, E., Butterbach-Bahl, K., 2010. Gross rates of ammonification and nitrification at a nitrogen-saturated spruce (Picea abies (L.) Karst.) stand in southern Germany. European Journal of Soil Science 61, 745-758.

Rothe, A., Huber, C., Kreutzer, K., Weis, W., 2002. Deposition and soil leaching in stands of Norway spruce and European beech: results from the Höglwald research in comparison with other European case studies. Plant and Soil 240, 33-45.

Saari, A., Smolander, A., Martikainen, P.J., 2004. Methane consumption in a frequently nitrogen-fertilized and limed spruce forest soil after clear-cutting. Soil Use and Management 20, 65-73.

Smith, K.A., Dobbie, K.E., Ball, B.C., Bakken, L.R., Sitaula, B.K., Hansen, S., Brumme, R., Borken, W., Christensen, S., Priemé, A., Fowler, D., Macdonald, J.A., Skiba, U., Klemedtsson, L., Kasimir-Klemedtsson, A., Degórska, A., Orlanski, P., 2000. Oxidation of atmospheric methane in Northern European soils, comparison with other ecosystems, and uncertainties in the global terrestrial sink. Global Change Biology 6, 791-803.

Steinkamp, R., Butterbach-Bahl, K., Papen, H., 2001. Methane oxidation by soils of an $\mathrm{N}$-limited and $\mathrm{N}$-fertilized spruce forest in the Black Forest, Germany. Soil Biology and Biochemistry 33, 145-153.

Sullivan, B.W., Kolb, T.E., Hart, S.C., Kaye, J.P., Dore, S., Montes-Helu, M., 2008. Thinning reduces soil carbon dioxide but not methane flux from southwestern USA ponderosa pine forests. Forest Ecology and Management 255, 4047-4055.

Tate, K.R., Ross, D.J., Saggar, S., Hedley, C.B., Dando, J., Singh, B.K., Lambie, S.M., 2007. Methane uptake in soils from Pinus radiata plantations, a reverting shrubland and adjacent pastures: effects of land-use change, and soil texture, water and mineral nitrogen. Soil Biology and Biochemistry 39, 1437-1449.

Teepe, R., Brumme, R., Beese, F., Ludwig, B., 2004. Nitrous oxide emission and methane consumption following compaction of forest soils. Soil Science Society of American Journal 68, 605-611.

Wu, X., Brüggemann, N., Gasche, R., Shen, Z., Wolf, B., Butterbach-Bahl, K., 2010a. Environmental controls over soil-atmosphere exchange of $\mathrm{N}_{2} \mathrm{O}, \mathrm{NO}$, and $\mathrm{CO}_{2}$ in a temperate Norway spruce forest. Global Biogeochemical Cycles 24, GB2012.

Wu, X., Yao, Z., Brüggemann, N., Shen, Z.Y., Wolf, B., Dannenmann, M., Zheng, X., Butterbach-Bahl, K., 2010b. Effects of soil moisture and temperature on $\mathrm{CO}_{2}$ and $\mathrm{CH}_{4}$ soil-atmosphere exchange of various land use/cover types in a semi-arid grassland in inner Mongolia, China. Soil Biology and Biochemistry 42, 773-787.

Yashiro, Y., Kadir, W.R., Okuda, T., Koizumi, H., 2008. The effects of logging on soil greenhouse gas $\left(\mathrm{CO}_{2}, \mathrm{CH}_{4}, \mathrm{~N}_{2} \mathrm{O}\right)$ flux in a tropical rain forest, Peninsular Malaysia. Agricultural and Forest Meteorology 148, 799-806.

Yavitt, J.B., Downey, D.M., Lang, G.E., Sexstone, A.J., 1990. Methane consumption in two temperate forest soils. Biogeochemistry 9, 39-52.

Zerva, A., Mencuccini, M., 2005. Short-term effects of clearfelling on soil $\mathrm{CO}_{2}, \mathrm{CH}_{4}$ and $\mathrm{N}_{2} \mathrm{O}$ fluxes in a Sitka spruce plantation. Soil Biology and Biochemistry 37, 2025-2036. 